\title{
DAMPAK COVID-19 TERHADAP ABNORMAL RETURN DAN VOLUME PERDAGANGAN SAHAM
}

\author{
Elvina Cahya Suryadi ${ }^{1}$, Nungky Viana Feranita ${ }^{2}$ \\ Sekolah Tinggi Ilmu Administrasi Pembangunan Jember ${ }^{1,2}$ \\ Email : efinacahya999@gmail.com ${ }^{1}$, \\ nungky_viana@stiapembangunanjember.ac.id ${ }^{2}$
}

\begin{abstract}
The COVID-19 pandemic is a non-natural disaster that has a huge impact around the world. This research is a quantitative research with event study method. The purpose of this research is to test the capital market reaction by looking at abnormal returns and trading volume activity before and after the COVID-19 non-natural disaster. The event day in this study was April 13 $3^{\text {rd }}, 2020$ when the Presidential Decree was issued regarding the designation of COVID-19 as a national disaster. Using purposive sampling method, the sample of this study were 27 companies engaged in the hotel, restaurant, and tourism sub-sectors listed on the Indonesia Stock Exchange. The event period is 11 days, namely 5 days before the event, 1 day at the time of the event and 5 days after the event. Data analysis using $t$-test and wilxocon signed ranks test. The results of this study are: 1) there is no abnormal return during the event period, 2) there is no difference in the average abnormal return before and after the COVID-19 non-natural disaster event, 3) there is no difference in the average trading volume activity before and after the COVID-19 non-natural disaster event and after the COVID-19 nonnatural disaster event.
\end{abstract}

Keywords: Event Study, Abnormal Return, Trading Volume Activity, COVID-19.

\section{Pendahuluan}

Pasar modal memiliki peran penting terhadap pertumbuhan ekonomi suatu negara, karena pasar modal menjadi sarana pendanaan usaha atau sarana bagi suatu perusahaan untuk mendapatkan modal dari investor. Pasar modal juga dapat memberikan reaksi akibat suatu peristiwa. Untuk mengetahui sejauh mana reaksi pasar modal dapat dilihat dari abnormal return dan volume perdagangan saham sebelum dan sesudah adanya peristiwa tersebut.

Menurut Hartono (2018), apabila dilihat dari sumber peristiwa, terdapat dua hal yang memengaruhi reaksi pasar modal yaitu peristiwa dari dalam dan dari luar perusahaan. Peristiwa dari dalam perusahaan, misalnya pengumuman mengenai 
laba perusahaan, pengumuman dividen, dan kejadian pemogokan karyawan. Peristiwa dari luar perusahaan dapat dilihat dari peristiwa ekonomi dan peristiwa non-ekonomi. Peristiwa ekonomi contohnya penguatan kurs dolar, perubahan suku bunga, kasus ekspor dan impor. Sedangkan untuk peristiwa non-ekonomi contohnya politik, pelanggaran HAM, peringatan hari-hari besar, dan bencana alam dan nonalam. Peristiwa dari luar perusahaan yang termasuk faktor nonekonomi yang saat ini terjadi di seluruh dunia yaitu bencana nonalam penyebaran COVID-19.

Corona Virus Disease 2019 atau yang biasa disebut COVID-19 merupakan jenis penyakit baru yang disebabkan oleh virus Severe Acute Respiratory Syndrome Coronavirus 2 (SARS-CoV-2). Data dari John Hopkins University \& Meidicine Coronavirus Resource Center per 15 Februari 2021 menunjukkan penularan COVID-19 sudah menjangkiti 192 negara dengan angka penularan sebanyak 108.881.648 kasus. Pada tanggal 13 April 2020 dikeluarkannya Keputusan Presiden No. 12 tahun 2020, tentang penetapan bencana non-alam penyebaran Corona Virus Disease 2019 (COVID-19) sebagai bencana nasional. Data dari Gugus Tugas Percepatan Penanganan COVID-19 per 15 Februari 2021 menunjukkan penularan COVID-19 sudah menjangkiti 34 provinsi di Indonesia dengan penambahan kasus sebanyak 6462 sehingga total angka penularan COVID-19 sebanyak 1.223.930 kasus.

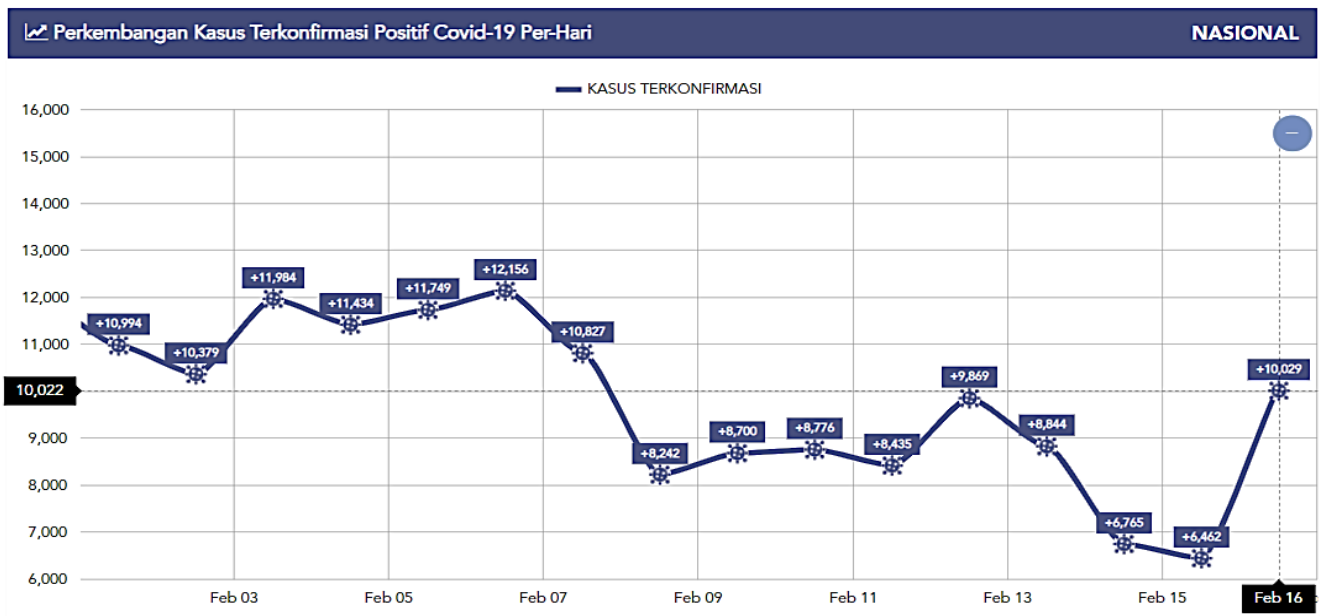

Gambar 1 Pertambahan Kasus Per Hari (Daily Increase) Nasional Sumber : Gugus Tugas Percepatan Penanganan COVID-19 
Dikeluarkannya Keputusan Presiden mengenai penetapan bencana non-alam COVID-19 sebagai bencana nasional sangat berdampak besar pada seluruh sektor industri di Indonesia, terutama pada sektor hotel, pariwisata dan restoran. Perhimpunan Hotel dan Restoran Indonesia (PHRI) mencatat pada tanggal 13 April 2020 pada saat COVID-19 dinyatakan sebagai bencana nasional sebanyak 1.642 hotel dari 31 Provinsi yang tutup akibat wabah virus corona dan bertambah hingga awal Mei 2020 sudah ada 2000 hotel yang tutup. Badan Pusat Statistik (BPS) mencatat jumlah tingkat hunian kamar hotel tahun 2020 mengalami penurunan dibandingkan tahun 2019, pada bulan April 2020 mengalami penurunan tajam dengan 12,67\%, Jika dibandingkan dengan April di tahun 2019, mengalami penurunan sebesar 41,23\%. Menteri Pariwisata dan Ekonomi Kreatif (Menparekraf) menyampaikan bahwa pariwisata mendapat imbas terparah karena COVID-19, dalam sektor pariwisata terdapat 13 juta pekerja pada sektor pariwisata dan 32,5 juta pekerja yang secara tidak langsung pekerjaannya terkait pariwisata yang berisiko terimbas dari bencana COVID-19 karena ditutupnya seluruh destinasi wisata untuk pencegahan penyebaran COVID-19. PHRI Bidang Restoran mencatat pada tanggal 19 April 2020 sebanyak 6.800 restoran tutup, karena ditutupnya 700 lebih mal atau pusat pembelanjaan yang di dalamnya berdiri gerai-gerai kuliner untuk mencegah penyebaran COVID-19. Survei Kegiatan Dunia Usaha (SKDU) Bank Indonesia menunjukkan bahwa sektor perdagangan, hotel, dan restoran pada triwulan II (kedua) tahun 2020 mengalami penurunan. Hal ini terlihat dari angka Saldo Bersih Tertimbang (SBT) kegiatan usaha sebesar $-7,21 \%$, lebih rendah pada triwulan I tahun 2020 sebesar dibandingkan -3,04\% dan SBT 4,17\% pada triwulan II tahun 2019.

Dari uraian permasalahan diatas dan fenomena yang terjadi, peneliti tertarik untuk menguji sejauh mana dampak COVID-19 terhadap abnormal return dan volume perdagangan saham, sebelum dan sesudah dikeluarkannya Keputusan Presiden mengenai penetapan COVID-19 sebagai bencana nasional pada Sub sektor hotel, restoran, dan pariwisata. Beberapa penelitian terdahulu yang meneliti reaksi pasar modal akan peristiwa COVID-19 telah dilakukan, diantaranya: (1) Siswantoro (2020) meneliti sektor yang sama dimana hasilnya menunjukkan 
bahwa terdapat perbedaan yang signifikan antara harga saham dan total perdagangan saham sebelum dan sesudah peristiwa, yang menjadi pembeda dengan penelitian ini yaitu penelitian tersebut tidak menganalisis abnormal return melainkan harga saham dan event day yang ditentukan; (2) Subrata dan Werastuti (2020); Khoiriah dkk (2020); Wicaksono dan Adyaksana (2020); dan Febriyanti (2020) meneliti variabel yang sama dan hasilnya menunjukkan bahwa terdapat perbedaan yang signifikan antara abnormal return dan volume perdagangan saham sebelum dan sesudah peristiwa, yang menjadi pembeda dengan penelitian ini yaitu perusahaan yang diteliti dan penentuan event day. Hasil penelitian terdahulu masih ada kontradiksi, yaitu penelitian dari Agustiawan dan Sujana (2020) dengan penelitian Subrata dan Werastuti (2020); Khoiriah dkk (2020); dan Febriyanti (2020) yang sama-sama meneliti abnormal return dan volume perdagangan saham pada perusahaan anggota indeks LQ45, tetapi hasil penelitiannya berbanding terbalik yaitu tidak terdapat perbedaan yang signifikan antara abnormal return dan volume perdagangan saham sebelum dan sesudah peristiwa.

Terdapat beberapa perbedaan dan ketidakkonsistenan hasil dari penelitianpenelitian terdahulu, sehingga penelitian tentang dampak COVID-19 terhadap abnormal return dan volume perdagangan saham tetap menarik untuk dilakukan.

\section{Tinjauan Pustaka}

\subsection{Tinjauan Penelitian Terdahulu}

Beberapa penelitian menyangkut penelitian event study, dimana penelitian tersebut menguji reaksi pasar modal akibat bencana non-alam COVID-19. Berikut disajikan beberapa penelitian tersebut.

1. Siswantoro (2020) melakukan penelitian yang bertujuan untuk mengetahui efek diumumkannya kasus pertama COVID-19 pada tanggal 2 Maret 2020 terhadap harga saham dan total saham yang diperdagangkan. Penelitian ini menemukan bahwa terdapat perbedaan yang signifikan antara harga saham dan total perdagangan saham sebelum dan sesudah pengumuman kasus pertama COVID-19 
2. Agustiawan dan Sujana (2020) melakukan penelitian yang bertujuan untuk mengetahui reaksi pasar modal indonesia sebelum dan sesudah pengumuman kebijakan pemerintah tentang status darurat bencana COVID-19. Penelitian ini menemukan bahwa tidak ditemukan perbedaan rata-rata abnormal return dan trading volume activity yang signifikan pada saham-saham LQ45.

3. Subrata dan Werastuti (2020) melakukan penelitian yang bertujuan mengetahui reaksi pasar pada penetapan status darurat global ke level tertinggi terkait virus corona oleh WHO (World Health Organization) pada Bursa Efek Indonesia. Penelitian ini menemukan bahwa terdapat perbedaan rata- rata yang signifikan abnormal return dan trading volume activity sebelum dan sesudah penetapan status darurat global ke level tertinggi terkait virus corona oleh WHO.

4. Khoiriah dkk (2020) melakukan penelitian yang bertujuan mengetahui pengaruh sebelum dan saat adanya pandemi COVID-19 terhadap saham LQ-45 di Bursa Efek Indonesia tahun 2020. Penelitian ini menemukan bahwa terdapat perbedaan rata-rata yang signifikan abnormal return dan trading volume activity terhadap saham LQ-45.

5. Wicaksono dan Adyaksana (2020) melakukan penelitian yang bertujuan untuk mengetahui analisis reaksi investor sebagai dampak Covid-19 pada sektor perbankan di Indonesia. Penelitian ini menemukan bahwa terdapat perbedaan abnormal return dan trading volume activity sebelum dan sesudah pengumuman COVID-19 sebagai pandemi global.

6. Febriyanti (2020) melakukan penelitian yang bertujuan untuk mengetahui dampak pandemi Covid-19 terhadap harga saham dan aktivitas volume perdagangan (Studi kasus saham LQ-45 di Bursa Efek Indonesia). Penelitian ini menemukan terdapat perbedaan rata- rata yang signifikan abnormal return dan trading volume activity perusahaan saham yang terdaftar di indeks LQ-45.

Berdasarkan beberapa acuan penelitian terdahulu, tampak adanya beberapa perbedaan diantaranya (1) penentuan event day, (2) sektor perusahaan, dan (3) hasil penelitian. Sehingga penelitian ini bermaksud untuk mengembangkan penelitian terdahulu dengan menguji bagaimana reaksi pasar modal akibat bencana non-alam COVID-19 tersebut masih menarik untuk diteliti. 


\subsection{Deskripsi Teori}

\subsubsection{Pasar Modal}

Menurut Hartono (2018), pasar modal adalah fasilitas perusahaan, yang meningkatkan kebutuhan dan jangka panjang dengan menjual saham dan menerbitkan obligasi. Pengertian pasar modal menurut Fahmi (2016) adalah tempat dimana berbagai pihak khususnya perusahaan yang menjual saham dan obligasi dengan tujuan dari hasil penjualan tersebut akan dipergunakan sebagai tambahan dana atau memperkuat modal perusahaan. Secara formal menurut Tandelilin (2010), pasar modal merupakan pasar untuk memperjualbelikan sekuritas yang umumnya memiliki umur lebih dari satu tahun, seperti saham dan obligasi, Dengan demikian dapat disimpulkan pasar modal merupakan pasar yang memperjual belikan berbagai instrumen keuangan jangka panjang seperti saham dan obligasi yang hasilnya dipergunakan untuk meningkatkan modal perusahaan.

\subsubsection{Pasar Modal yang Efisien}

Pasar modal yang efisien menurut Tandelilin (2010) adalah pasar dimana harga semua sekuritas yang diperdagangkan telah mencerminkan semua informasi yang tersedia. Menurut Harjito dan Martono (2012), pasar modal yang efisien adalah ketika harga-harga sekuritas yang ada di pasar modal mencerminkan informasi relevan yang memengaruhi harga sekuritas tersebut. Sedangkan menurut Nursiam dan Puteranto (2004), pasar yang efisien merupakan suatu pasar bursa dimana efek yang diperdagangkan merefleksikan semua informasi yang mungkin terjadi dengan cepat dan akurat. Dengan demikian dapat disimpulkan pasar modal yang efisien adalah keadaan pasar dimana harga semua saham yang diperdagangkan mencerminkan atau sesuai dengan semua informasi yang terjadi.

\subsubsection{Saham}

Saham menurut Rusdin (2008:68) merupakan sertifikat yang menunjukkan bukti akan kepemilikan suatu perusahaan, dan pemegang saham memiliki hak atas penghasilan dan aktiva perusahaan tersebut. Menurut Fahmi (2016), Saham adalah kertas yang tercantum dengan jelas nilai nominal, nama perusahaan, dan diikuti 
dengan hak dan kewajiban yang telah dijelaskan kepada setiap pemegangnya. Menurut Darmadji dan Fakhruddin (2012:5), saham adalah tanda penyertaan atau pemilikan seseorang atau badan dalam suatu perusahaan atau perseorangan terbatas, saham berwujud selembar kertas yang menerangkan bahwa pemilik kertas tersbut adalah pemilik perusahaan yang menerbitkan surat berharga tersebut. Dengan demikian dapat disimpulkan saham merupakan surat berharga yang menyatakan bagian kepemilikan atas suatu perusahaan yang diperdagangkan dipasar modal dengan memiliki saham suatu perusahaan berarti seseorang atau badan usaha telah menjadi bagian dari pemilik perusahaan tersebut sehingga berhak atas imbal hasil (return) yang dihasilkan oleh perusahaan tersebut sesuai dengan porsi tertentu.

\subsubsection{Return dan Abnormal Return}

Menurut Hartono (2018:63), Return adalah hasil yang diperoleh dari kegiatan investasi dapat berupa return realisasian yang telah terjadi atau return ekspektasi yang belum terjadi tetapi yang diharapkan akan terjadi. Return realisasi ialah return yang sesungguhnya yang telah terjadi, rumus menghitung return realisasi, menurut Hartono (2018) sebagai berikut:

$$
R_{i, t}=\frac{P_{i, t}-P_{i, t-1}}{P_{i, t-1}}
$$

keterangan:

$\mathrm{Ri}, \mathrm{t}=$ return sesungguhnya saham ke-i pada hari ke-t

$\mathrm{Pi}, \mathrm{t} \quad=$ harga saham ke-i pada hari ke-t

$\mathrm{Pi}, \mathrm{t}-1$ = harga saham ke-i pada hari ke-t-1

Return ekspektasi ialah return normal atau rerturn yang diharapkan oleh invesor, Dalam menghitung return ekspektasi menurut Hartono (2018), sebagai berikut:

$$
E\left(R_{i, t}\right)=\alpha_{i}+\beta_{i} \cdot E\left(R_{m, t}\right)
$$

keterangan:

$\mathrm{E}(\mathrm{Ri}, \mathrm{t}) \quad=$ return ekspektasi untuk saham ke-i pada hari ke-t

$\mathrm{Rm}, \mathrm{t}=$ return pasar pada hari ke-t 
Menurut Hartono (2018:94), abnormal return merupakan kelebihan dari return yang sesungguhnya terjadi (actual return) terhadap return normal. return normal merupakan return ekspektasi (expected return) atau return yang diharapkan oleh investor. Cara menghitung abnormal return, menurut Hartono (2018) sebagai berikut:

$$
A R_{i, t}=R_{i, t}-E\left(R_{i, t}\right)
$$

keterangan:

$\mathrm{ARi}, \mathrm{t}=$ return tidak normal saham ke-i pada hari ke-t

$\mathrm{Ri}, \mathrm{t}=$ return sesungguhnya untuk saham ke-i pada hari ke-t

$\mathrm{E}(\mathrm{Ri}, \mathrm{t}) \quad=$ return ekspektasi untuk saham ke-i pada hari ke- $\mathrm{t}$

\subsubsection{Volume Perdagangan Saham}

Volume perdagangan saham (Trading Volume Activity) merupakan rasio antara jumlah lembar saham yang diperdagangkan pada waktu tertentu terhadap jumlah saham yang beredar pada waktu tertentu (Husnan, 2009:283). Volume perdagangan merupakan suatu instrumen yang dapat digunakan untuk melihat reaksi pasar modal terhadap informasi melalui parameter volume saham yang diperdagangkan di pasar (Sutrisno, 2010). Volume perdagangan saham adalah jumlah lembar saham yang diperdagangkan secara harian (Hartono, 2015). Dapat disimpulkan bahwa volume perdagangan saham merupakan jumlah lembar saham yang diperdagangkan dalam kurun waktu tertentu yang dapat dipergunakan untuk melihat reaksi pasar modal. Menurut Tandelilin (2010) dalam menghitung volume perdagangan saham, menggunakan rumus sebagai berikut:

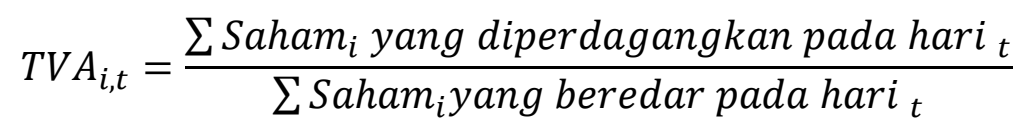

\subsubsection{Event Study}

Studi untuk menguji reaksi pasar terhadap suatu event (peristiwa) yang informasinya dipublikasikan sebagai suatu pengumuman disebut studi peristiwa (Hartono, 2018). Event study adalah penelitian yang mengamati dampak dari pengumuman informasi terhadap harga sekuritas. Penelitian event study umumnya 
berkaitan dengan seberapa cepat suatu informasi yang masuk ke pasar dapat tercermin pada harga saham (Tandelilin, 2010). Event study adalah suatu metodologi yang banyak digunakan dalam penelitian di bidang keuangan (Ahern, 2006). Dapat diartikan juga studi peristiwa adalah studi mengenai pengujian dalam melihat reaksi pasar terhadap suatu peristiwa yang berisi informasi untuk dipublikasikan sebagai pengumuman.

\subsection{Kerangka Pemikiran}

Kerangka pemikiran pada penelitian ini dapat dilihat, sebagai berikut:

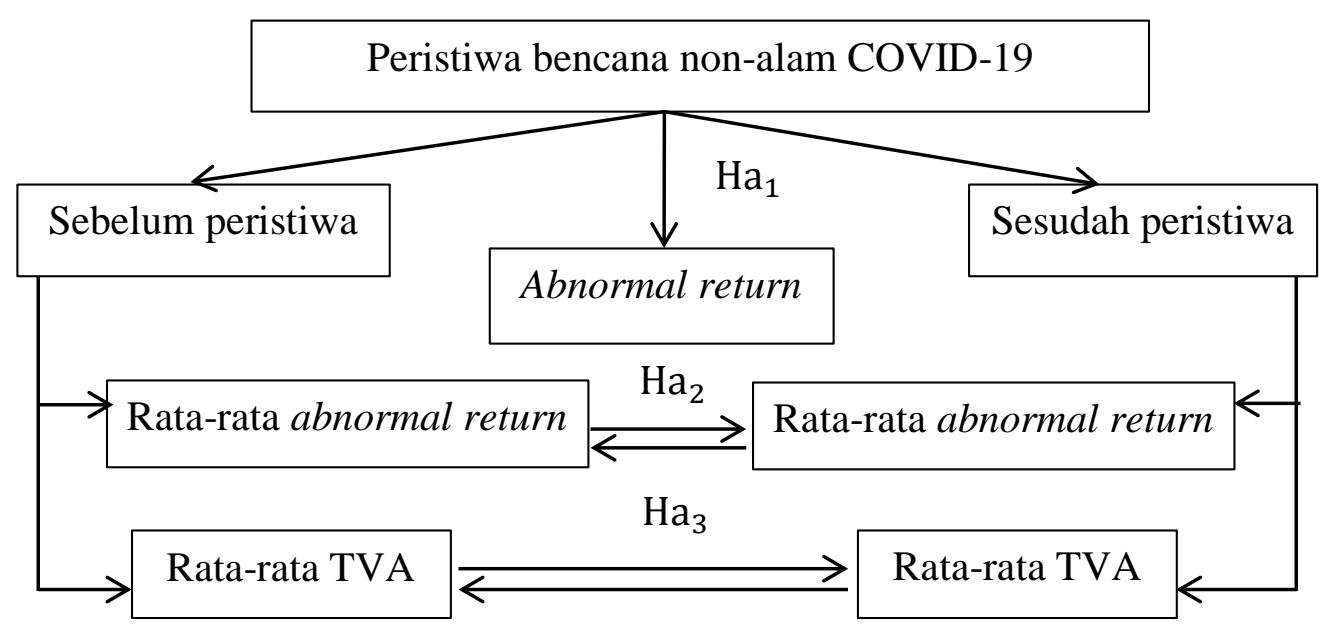

Gambar 2. Kerangka Pemikiran

\subsection{Hipotesis}

Berdasarkan kerangka pemikiran yang diatas, maka hipotesis dalam penelitian ini adalah:

$\mathrm{Ha}_{1}$ : Terdapat abnormal return saham selama periode peristiwa bencana nonalam COVID-19.

$\mathrm{Ha}_{2}$ : Terdapat perbedaan rata-rata abnormal return saham sebelum dan setelah peristiwa bencana nonalam COVID-19.

$\mathrm{Ha}_{3}$ : Terdapat perbedaan rata-rata aktivitas volume perdagangan saham sebelum dan setelah peristiwa bencana nonalam COVID-19. 


\section{Metode Penelitian}

\subsection{Jenis dan Tipe Penelitian}

Jenis penelitian ini adalah penelitian kuantitatif dengan metode studi peristiwa (event study). Penelitian ini menggunakan pendekatan deskriptif untuk menguji hipotesis 1 serta pendekatan komparatif untuk menguji hipotesis 2 dan 3 . Jenis risetnya adalah riset empirik dimana riset yang dilakukan dengan alat ukur yang jelas tervalidasi dalam mengumpulkan data.

\subsection{Tempat dan Waktu}

Dalam penelitian ini pasar modal yang diteliti adalah Bursa Efek Indonesia (BEI). Periode pengamatan dalam event study dibagi menjadi dua yaitu periode estimasi dan periode peristiwa. Dalam penelitian ini periode pengamatan yang digunakan adalah : 1) Periode estimasi ditetapkan selama 65 hari bursa sebelum periode jendela, mulai tanggal 31 Desember 2019 sampai dengan tanggal 2 April 2020, 2) Periode jendela selama 11 hari bursa yaitu 5 hari sebelum peristiwa (3 April 2020 - 9 April 2020), 1 hari pada saat peristiwa (13 April 2020), dan 5 hari setelah peristiwa (14 April 2020 - 20 April 2020).

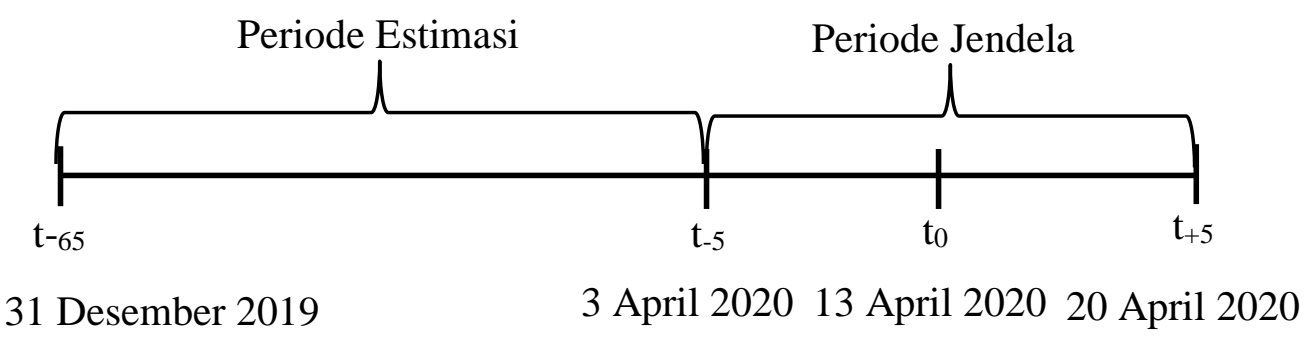

Gambar 3. Periode Waktu Penelitian

\subsection{Populasi dan Sampel}

Populasi dalam penelitian ini adalah seluruh perusahaan sub sektor hotel, restoran, dan pariwisata yang terdaftar di BEI tercatat sebanyak 34 perusahaan. Pengambilan sampel dalam penelitian ini menggunakan teknik non probability yaitu purposive sampling. Kriteria yang digunakan yaitu: (1) perusahaan tersebut terdaftar di BEI selama periode pengamatan; dan (2) terdapat perubahan harga 
saham selama periode pengamatan. Sehingga sampel yang diperoleh pada penelitian ini sebanyak 27 perusahaan.

\subsection{Teknik Pengumpulan data}

Data yang digunakan dalam penelitian ini adalah data sekunder yang meliputi data saham-saham dari perusahaan yang bergerak di sub sektor hotel, pariwisata dan restoran yang terdaftar di Bursa Efek Indonesia hingga 15 Februari 2021 sebagai sampel dalam penelitian ini, serta volume perdagangan saham harian dan jumlah saham beredar harian selama periode peristiwa yaitu 5 hari sebelum event day dan 5 hari setelah event day.

Teknik pengambilan data menggunakan teknik dokumentasi. Data tersebut di dapat dan dikutip di internet dari situs Bursa Efek Indonesia atau Indonesia Stock Exchange dengan URL: https://www.idx.co.id/ dan merupakan sumber data yang relevan untuk penelitian ini.

\subsection{Teknik Analisis Data}

Teknik analisis data pada penelitian ini, diantaranya:

1. Statistik Deskriptif

Statistik deskriptif merupakan uji statistik yang digunakan dalam menganalisis data dengan mendeskripsikan data yang telah terkumpul. Dalam penelitian ini data yang deskripsikan adalah Abnormal Return (AR), Trading Volume Activity (TVA), Average Abnormal Return (AAR), Cumulative Average Abnormal Return (CAAR) dan Average Trading Volume Activity (ATVA).

2. Uji Normalitas

Uji normalitas yang digunakan adalah uji Kolmogorov-Smirnov dengan taraf signifikansi atau alpha $(\alpha) 0,05$ atau 5\%. Kriteria penerimaan pada uji normalitas adalah: 1) Jika nilai sig > 0,05 maka data berdistribusi normal, 2) Jika nilai sig $<0,05$ maka data berdistribusi tidak normal.

3. Uji Hipotesis

Uji hipotesis yang digunakan dalam penelitian ini adalah uji beda. Uji beda 
yang digunakan tergantung hasil dari uji normalitas. Apabila data tersebut berdistribusi normal, maka uji beda yang dilakukan dalam penelitian ini menggunakan uji beda statistik parametrik one sampel t-test dan paired sample t-test. Apabila data tersebut tidak berdistribusi normal maka uji beda yang digunakan adalah uji beda statistik non parametrik wilcoxon signed rank test, dengan tingkat signifikansi yaitu 5\%.

Gambar berikut merupakan tahapan yang dilaksanakan dalam penelitian ini.

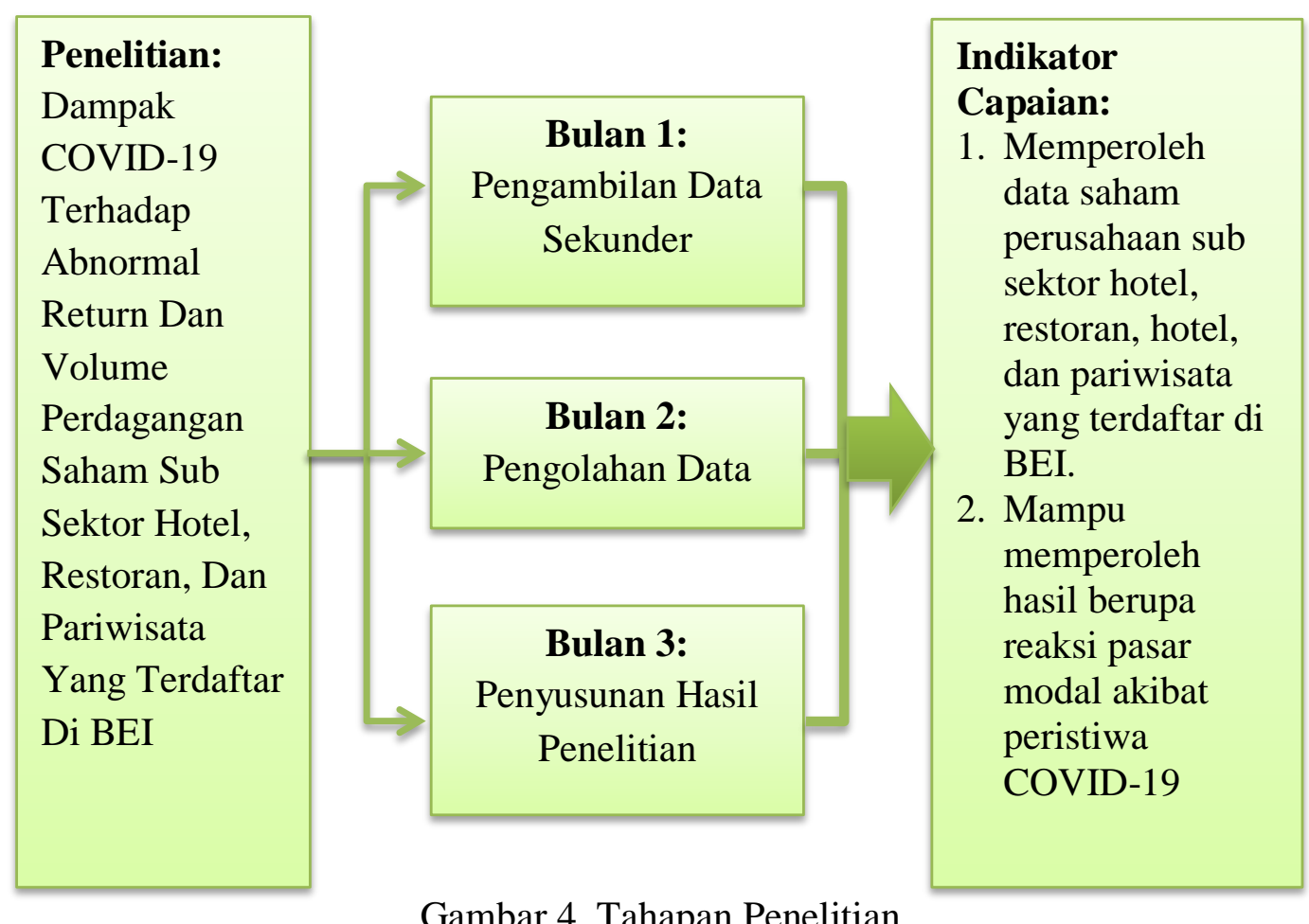

\section{Hasil Dan Pembahasan}

\subsection{Pengujian Hipotesis 1}

Pengujian hipotesis pertama dalam penelitian ini dimaksudkan untuk mengetahui ada tidaknya abnormal return saham selama periode peristiwa bencana nonalam COVID-19. Berdasarkan Tabel 1 menunjukkan hasil uji normalitas, dimana hanya $\mathrm{t}+1$ yang berdistribusi tidak normal, sehingga untuk $\mathrm{t}+1$ uji hipotesis yang dilakukan menggunakan one-sample wilcoxon signed rank test. Sedangkan untuk t-5, t-4, t-3, t-2, t-1,t0, t+2, t+3, t+4, dan $\mathrm{t}+5$ dimana berdistribusi normal, uji hipotesis yang dilakukan menggunakan one sample t-test. 
Tabel 1. Uji Normalitas Abnormal Return

\begin{tabular}{|c|c|c|c|}
\hline Hari ke-t & Sig & Ket & Kesimpulan \\
\hline $\mathrm{t}-5$ & 0,143 & $>0,05$ & Normal \\
\hline $\mathrm{t}-4$ & 0,79 & $>0,05$ & Normal \\
\hline $\mathrm{t}-3$ & 0,201 & $>0,05$ & Normal \\
\hline $\mathrm{t}-2$ & 0,100 & $>0,05$ & Normal \\
\hline $\mathrm{t}-1$ & 0,197 & $>0,05$ & Normal \\
\hline $\mathrm{t} 0$ & 0,482 & $>0,05$ & Normal \\
\hline $\mathrm{t}+1$ & 0,29 & $<0,05$ & Tidak Normal \\
\hline $\mathrm{t}+2$ & 0,600 & $>0,05$ & Normal \\
\hline $\mathrm{t}+3$ & 0,831 & $>0,05$ & Normal \\
\hline $\mathrm{t}+4$ & 0,857 & $>0,05$ & Normal \\
\hline $\mathrm{t}+5$ & 0,387 & $>0,05$ & Normal \\
\hline
\end{tabular}

Sumber: Output Uji Normalitas Abnormal Return

Berdasarkan Tabel 2 menunjukkan hasil uji one sample t-test untuk t-5, t$4, \mathrm{t}-3, \mathrm{t}-2, \mathrm{t}-1, \mathrm{t} 0, \mathrm{t}+2, \mathrm{t}+3, \mathrm{t}+4$, dan $\mathrm{t}+5$ nilai signifikannya lebih dari 0,05 , yang artinya tidak ada abnormal return.

Tabel 2. Hasil Uji Abnormal Return Selama Periode Peristiwa

\begin{tabular}{|c|c|c|c|}
\hline Hari ke-t & Sig & Ket & Kesimpulan \\
\hline$t-5$ & 0,750 & $>0,05$ & \multirow[t]{10}{*}{$\mathrm{Ha}_{1}$ ditolak } \\
\hline $\mathrm{t}-4$ & 0,976 & $>0,05$ & \\
\hline$t-3$ & 0,148 & $>0,05$ & \\
\hline$t-2$ & 0,647 & $>0,05$ & \\
\hline $\mathrm{t}-1$ & 0,068 & $>0,05$ & \\
\hline t0 & 0,801 & $>0,05$ & \\
\hline$t+2$ & 0,579 & $>0,05$ & \\
\hline$t+3$ & 0,578 & $>0,05$ & \\
\hline$t+4$ & 0,420 & $>0,05$ & \\
\hline$t+5$ & 0,762 & $>0,05$ & \\
\hline
\end{tabular}

Sumber: Output one sample t-test

Berdasarkan Tabel 3 menunjukkan hasil dari uji one sample wilcoxon signed rank test untuk t+1 diperoleh nilai signifikannya lebih dari 0,05 yaitu 0,981. Artinya tidak ada abnormal return pada $\mathrm{t}+1$.

Tabel 3. Hasil Uji Abnormal Return Selama Periode Peristiwa

\begin{tabular}{|c|c|c|c|}
\hline Hari ke-t & Sig & Ket & Kesimpulan \\
\hline $\mathrm{t}+1$ & 0,981 & $>0,05$ & $\mathrm{Ha}_{1}$ ditolak \\
\hline
\end{tabular}


Sehingga dapat disimpulkan bahwa tidak terdapat abnormal return selama periode peristiwa bencana COVID-19, maka hipotesis pertama ( $\left.\mathrm{Ha}_{1}\right)$ ditolak. Hasil penelitian ini sejalan dengan penelitian dari Sambuari dkk (2020), dimana hasil penelitiannya menyatakan bahwa tidak terdapat abnormal return pada perusahaan makanan dan minuman yang terdaftar di BEI.

Dengan hasil penelitian yang memunjukkan tidak adanya abnormal return selama periode jendela ini mencerminkan bahwa peristiwa dikeluarkannya keputusan presiden akan penetapan COVID-19 sebagai bencana nasional tidak mengandung informasi yang kuat menyebabkan reaksi pasar modal yang signifikan. Hal tersebut dapat terjadi karena dikeluarkannya keputusan presiden akan penetapan COVID-19 sebagai bencana nasional tersebut hanya tindakan lanjut untuk penanganan dan pencegahan COVID-19 di Indonesia, serta keputusan presiden tersebut keluar setelah COVID-19 sudah menyebar keseluruh Indonesia. Mengingat penyebaran COVID-19 sendiri sudah menyebar ke seluruh dunia sejak awal tahun 2020 dan WHO secara resmi menyatakan COVID-19 sebagai pandemi pada tanggal 11 Maret 2020, sehingga kemungkinan pasar sudah dapat memprediksi akan peristiwa tersebut. Hal tersebut dibuktikan dengan menurunnya IHSG sektor perdagangan, jasa dan investasi mulai bulan januari sampai dengan maret 2020. Dengan menurunnya IHSG sektor perdagangan, jasa dan investasi, pasar sudah menyiapkan strategi bagaimana menanggapi penyebaran COVID-19, pada periode berikutnya pasar modal sudah dapat menunjukkan kondisi yang stabil dengan terciptanya harga keseimbangan baru.

\subsection{Pengujian Hipotesis 2}

Pengujian hipotesis kedua dalam penelitian ini untuk mengetahui ada tidaknya perbedaan rata-rata abnormal return saham sebelum dan setelah peristiwa bencana nonalam COVID-19.

Tabel 4. Hasil Uji Normalitas Average Abnormal Return

\begin{tabular}{|c|c|c|c|}
\hline & Signifikansi & Keterangan & Kesimpulan \\
\hline AAR sebelum & 0,200 & $>0,05$ & Normal \\
\hline AAR sesudah & 0,128 & $>0,05$ & Normal \\
\hline
\end{tabular}

Sumber: Output Uji Normalitas Average Abnormal Return 
Berdasarkan Tabel 4 menunjukkan hasil pengujian normalitas dari average abnormal return pada periode sebelum dan sesudah pristiwa. Hasilnya menunjukkan bahwa kedua data tersebut terdistribusi normal karena memiliki nilai sig lebih besar dari 0,05 .

Tabel 5. Hasil Uji Average Abnormal Return Sebelum dan Sesudah Peristiwa

\begin{tabular}{|c|l|c|c|}
\hline \multicolumn{2}{|c|}{ SEBELUM } & \multicolumn{2}{c|}{ SESUDAH } \\
\hline \multicolumn{1}{|c|}{ Hari ke-t } & \multicolumn{1}{|c|}{ AAR } & Hasti ke-t & AAR \\
\hline-5 & $-0,00349731$ & +1 & 0,011088054 \\
\hline-4 & 0,000306535 & +2 & $-0,00454763$ \\
\hline-3 & $-0,01132662$ & +3 & $-0,00493687$ \\
\hline-2 & 0,005709361 & +4 & $-0,00618722$ \\
\hline-1 & $-0,01275629$ & +5 & 0,001932709 \\
\hline Mean & $-0,0037826734$ & & \\
\hline Std. Deviation & 0,0118625116 & & \\
\hline Sig & 0,515 & & \\
\hline Keterangan & $>0,05$ & \\
\hline Kesimpulan & $\mathrm{Ha}_{2}$ ditolak \\
\hline
\end{tabular}

Sumber: Output uji paired sample t-test

Berdasarkan Tabel 5 yaitu hasil uji paired sample t-test dapat disimpulkan bahwa tidak terdapat perbedaan rata-rata abnormal return saham sebelum dan setelah peristiwa, maka hipotesis kedua $\left(\mathrm{Ha}_{2}\right)$ ditolak. Hasil penelitian ini sejalan dengan penelitian dari Agustiawan dan Sujana (2020), dimana hasil penelitiannya menyatakan bahwa tidak ditemukan perbedaan rata-rata abnormal return dan trading volume activity yang signifikan pada saham-saham LQ45.

Dengan tidak adanya average abnormal return sebelum dan sesudah peristiwa dikeluarkannya keputusan presiden akan penetapan COVID-19 sebagai bencana nasional, hal ini mencerminkan bahwa para investor tidak melakukan aktivitas di atas normal dan melakukan aktivitas jual beli saham seperti biasa. Melihat hal tersebut dapat diartikan bahwa para investor sangat berhati-hati dalam bersikap dan sangat memperhitungkan adanya kemungkinan jangka panjang. Faktor yang menyebabkan tidak adanya average abnormal return, selain peristiwa dikeluarkannya keputusan presiden akan penetapan COVID-19 sebagai bencana 
nasional sudah dapat diprediksi oleh pasar modal sehingga pasar sudah menyiapkan strategi bagaimana menanggapi penyebaran COVID-19 agar pasar modal sudah dapat menunjukkan kondisi yang stabil pada periode berikutnya, ada juga faktor lainnnya yaitu penentuan rentan waktu pada periode jendela yang pendek.

Pada penelitian ini periode jendela yang ditentukan selama 11 hari bursa yaitu 5 hari sebelum peristiwa, 1 hari pada saat peristiwa, dan 5 hari setelah peristiwa. Alasan peneliti mengambil 5 hari sebelum dan 5 hari sesudah peristiwa, serta tidak mengambil 10 hari sebelum dan 10 hari sesudah peristiwa atau lebih dalam penelitian ini, karena pada 10 hari sebelum peristiwa atau lebih ada peristiwa lainnya yaitu pada tanggal 30 Maret 2020 Presiden Joko Widodo menetapkan pembatasan sosial berskala besar dan ada juga peristiwa bencana alam lainnya yaitu meletusnya gunung merapi pada tanggal 27 Maret 2020. Menurut Hartono (2018), dalam menentukan periode jendela harus dipastikan tidak ada peristiwa pengganggu. Dengan memilih 10 hari sebelum dan 10 hari sesudah peristiwa atau lebih dalam penelitian ini kemungkinan reaksi pasar dapat dipengaruhi, tetapi untuk mendapatkan reaksi pasar atas cerminan dari peristiwa dikeluarkannya keputusan presiden akan penetapan COVID-19 sebagai bencana nasional itu sendiri tidak sesuai atau tidak murni, karena dalam periode jendela tersebut terdapat peristiwa lainnya. Periode jendela yang telah ditentukan oleh peneliti yaitu 5 hari sebelum dan sesudah peristiwa tidak ada peristiwa pengganggu di dalamnya.

\subsection{Pengujian Hipotesis 3}

Pengujian hipotesis ketiga dalam penelitian ini untuk mengetahui ada tidaknya perbedaan average trading volume activity saham sebelum dan setelah peristiwa bencana nonalam COVID-19.

Tabel 6. Hasil Uji Normalitas Average Trading Volume Activity

\begin{tabular}{|c|c|c|c|}
\hline & Signifikansi & Keterangan & Kesimpulan \\
\hline AVTA sebelum & 0,053 & $>0,05$ & Normal \\
\hline AVTA sesudah & 0,200 & $>0,05$ & Normal \\
\hline
\end{tabular}

Sumber: Output Uji Normalitas ATVA 
Berdasarkan Tabel 6 menunjukkan hasil pengujian normalitas dari average trading volume activity pada periode sebelum dan sesudah pristiwa. Hasilnya menunjukkan bahwa kedua data tersebut terdistribusi normal karena memiliki nilai sig lebih besar dari 0,05 .

Tabel 7. Hasil Uji ATVA Sebelum dan Sesudah Peristiwa

\begin{tabular}{|c|l|c|c|}
\hline \multicolumn{2}{|c|}{ SEBELUM } & \multicolumn{2}{c|}{ SESUDAH } \\
\hline Hari ke-t & \multicolumn{1}{|c|}{ AVTA } & Hasti ke-t & \multicolumn{1}{c|}{ AVTA } \\
\hline-5 & 0,000407616 & +1 & 0,000488154 \\
\hline-4 & 0,000488391 & +2 & 0,00176889 \\
\hline-3 & 0,000792587 & +3 & 0,001071634 \\
\hline-2 & 0,000435753 & +4 & 0,000585714 \\
\hline-1 & 0,000408151 & +5 & 0,001549902 \\
\hline Mean & $-0,0005863593$ & & \\
\hline Std. Deviation & 0,0005768510 & & \\
\hline Sig & 0,085 & \multicolumn{2}{l}{} \\
\hline Keterangan & $>0,05$ & \\
\hline Kesimpulan & Ha 3 ditolak & \\
\hline
\end{tabular}

Sumber: Output Uji Paired Sample T-Test

Berdasarkan Tabel 7 yaitu hasil uji paired sample t-test dapat disimpulkan bahwa tidak terdapat perbedaan rata-rata aktivitas volume perdagangan saham sebelum dan setelah peristiwa, maka hipotesis ketiga $\left(\mathrm{Ha}_{3}\right)$ ditolak. Hasil penelitian ini sejalan dengan penelitian dari Agustiawan dan Sujana (2020), dimana hasil penelitiannya menyatakan bahwa tidak ditemukan perbedaan ratarata abnormal return dan trading volume activity yang signifikan pada sahamsaham LQ45.

Tidak adanya perbedaan rata-rata aktivitas volume perdagangan saham sebelum dan setelah peristiwa dikeluarkannya keputusan presiden akan penetapan COVID-19 sebagai bencana nasional, ini menunjukkan bahwa para investor tidak terlalu menanggapi peristiwa yang terjadi. Para investor sudah memahami dampak yang akan terjadi, bahwa COVID-19 ini merupakan bencana yang tidak bisa berhenti secara langsung saat itu juga. Hal tersebut didukung oleh penelitian Kuniya (2020) dimana hasil penelitiannya mengatakan COVID-19 memberikan 
intervensi dalam jangka waktu yang relatif lama. Selain itu, penelitian Haryanti dan Pamukti (2020) menunjukkan bahwa puncak wabah COVID-19 di Indonesia untuk model logistik terjadi pada 23 April 2021 sedangkan model gompertz terjadi pada 30 Mei 2024. Dengan adanya prediksi tersebut para investor mencoba beradaptasi dengan kondisi yang terjadi agar pasar modal dapat menunjukkan kondisi yang stabil selama pandemi COVID-19, maka dari itu, pada saat dikeluarkannya keputusan presiden aktivitas pasar sudah stabil dan investor melakukan transaksi jual beli seperti biasa. Dengan hasil dikeluarkannya keputusan presiden akan penetapan COVID-19 sebagai bencana nasional yang tidak memberikan reaksi pasar modal yang signifikan, dapat diartikan peristiwa tersebut tidak mengandung informasi yang kuat untuk pasar modal. Keadaan pasar modal yang mulai stabil tentunya sangat berarti bagi investor, seperti yang kita ketahui munculnya COVID-19 merupakan bencana yang memberikan dampak sangat besar di seluruh sektor dan kehidupan bermasyarakat. Investor pastinya beranggapan dimasa pandemi ini lebik pasar modal stabil dari pada pasar modal memberikan reaksi negatif, karena jika pasar modal memberikan reaksi negatif akan menyebabkan penurunan aktivitas perdagangan saham di pasar modal Indonesia sehingga pastinya akan mempengauhi perekonomian Indonesia.

\section{Kesimpulan dan Saran}

\subsection{Kesimpulan}

Berdasarkan pembahasan hasil penelitian, dapat ditarik beberapa kesimpulan sebagai berikut:

1. Tidak terdapat abnormal return saham selama periode peristiwa bencana nonalam COVID-19, hal ini mencerminkan bahwa peristiwa dikeluarkannya keputusan presiden akan penetapan COVID-19 sebagai bencana nasional tidak mengandung informasi yang kuat untuk menyebabkan reaksi pasar modal yang signifikan.

2. Tidak terdapat perbedaan rata-rata abnormal return saham sebelum dan setelah peristiwa bencana nonalam COVID-19, hal ini mencerminkan bahwa para investor tidak melakukan aktivitas di atas normal dan melakukan 
aktivitas jual beli saham seperti biasa pada saat peristiwa dikeluarkannya keputusan presiden akan penetapan COVID-19 sebagai bencana nasional.

3. Tidak terdapat perbedaan rata-rata aktivitas volume perdagangan saham sebelum dan setelah peristiwa bencana nonalam COVID-19, hal ini mencerminkan bahwa pada saat dikeluarkannya keputusan presiden aktivitas pasar sudah stabil dan investor melakukan transaksi jual beli seperti biasa.

\subsection{Saran}

Berdasarkan penelitian diatas, terdapat beberapa saran yang dapat diberikan yaitu sebagai berikut:

1. Bagi peneliti selanjutnya yang akan melakukan penelitian event study, disarankan untuk menambah variabel yang lebih banyak seperti security return variability, menentukan rentang waktu pengamatan yang lebih panjang dan meneliti perusahaan sektor lainnya. Dengan begitu, diharapkan adanya peningkatan pada kualitas dan keakuratan dari hasil penelitian serta hasil penelitian akan lebih luas dan bervariasi

2. Peneliti selanjutnya juga diharapkan dalam menentukan suatu peristiwa selama periode jendela dan periode estimasinya tidak terdapat peristiwa pengganggu atau peristiwa lainnya agar hasil dari reaksi pasar merupakan dampak dari peristiwa yang dipilih.

\section{DAFTAR PUSTAKA}

Agustiawan, K.E., dan Sujana, Edy. 2020. Reaksi Pasar Modal Indonesia Sebelum Dan Sesudah Pengumuman Kebijakan Pemerintah Tentang Status Darurat Bencana Covid-19. Jurnal Akuntansi Profesi. 11(2):293-302

Ahern, K.R. 2006. Sample Selection and Event Study Estimation. Los Angeles: University of California.

Badan Pusat Statistik. 2020. Tingkat Penghunian Kamar pada Hotel Bintang di $\begin{array}{llll}\text { Indonesia, } & 2008 & - & 2020 .\end{array}$ https://www.bps.go.id/linkTableDinamis/view/id/980. Diakses tanggal 15 Februari 2021. 
Bursa Efek Indonesia. 2021. Daftar Saham. URL: https://www.idx.co.id/datapasar/data-saham/daftar-saham/. Diakses tanggal 17 Februari 2021.

Darmadji, Tjiptono, dan Fakhruddin. 2012. Pasar Modal Di Indonesia. Edisi. Ketiga. Jakarta : Salemba Empat.

Departemen Komunikasi Bank Indonesia. 2021. Survei Kegiatan Dunia Usaha Triwulan IV 2020 : Kegiatan Dunia Usaha Membaik . URL: https://www.bi.go.id/id/publikasi/ruangmedia/newsrelease/Pages/sp_231121 .aspx. Diakses tanggal 15 Februari 2021.

Fahmi, Irham. 2016. Pengantar Manajemen Keuangan. Bandung : ALFABETA, CV.

Febriyanti, G.A. 2020. Dampak pandemi Covid-19 terhadap harga saham dan aktivitas volume perdagangan (Studi kasus saham LQ-45 di Bursa Efek Indonesia). Indonesia Akuntansi Jurnal. 2(2):204-214.

Gugus Tugas Percepatan Penanganan COVID-19. 2021. Pertambahan Kasus Per Hari (Daily Increase) Nasional. URL: https://covid19.go.id/peta-sebaran. Diakses tanggal 15 Februari 2021.

Harjito, D.A \& Martono. 2012. Manajemen Keuangan Edisi ke dua. Yogyakarta: Ekonisia.

Hartono, Jogiyanto. 2015. Teori Portofolio dan Analisis Investasi. Edisi kw-8, BPFE. Yogyakarta.

Hartono, Jogiyanto. 2018. Menguji Reaksi Pasar Modal akibat Suatu Peristiwa. Edisi ke1, BPFE. Yogyakarta.

Haryanti, T \& Pamukti, B. 2020. A Comparison of The Predictive Ability between Logistic and Gompertz Model on COVID-19 Outbreak. International Journal of Applied Information Technology. 4(2): 57-68.

Husnan, Suad. 2009. Dasar-dasar Teoti Portofolio \& Analisis Sekuritas. Edisi keempat. Yogyakarta : UPP STIM YKPN.

John Hopkins University \& Meidicine. 2021. Coronavirus Resource Center. URL: https://coronavirus.jhu.edu/map.html. Diakses tanggal 15 Februari 2021. 
Kementerian Pariwisata dan Ekonomi Kreatif / Badan Pariwisata dan Ekonomi Kreatif Republik Indonesia. 2020. Statistik Kunjungan Wisatawan Mancanegara 2020. URL: https://www.kemenparekraf.go.id/statistikwisatawan-mancanegara/Statistik-Kunjungan-Wisatawan-Mancanegara2020. Diakses tanggal 15 Februari 2021.

Khoiriah, M., Amin, M., dan Kartikasari, A.F., 2020. Pengaruh Sebelum Dan Saat Adanya Pandemi Covid-19 Terhadap Saham Lq-45 Di Bursa Efek Indonesia Tahun 2020. E-JRA. 9(11):117-126.

Kuniya, Toshikazu. 2020. Prediction Of The Epidemic Peak Of Coronavirus Disease In Japan 2020. Clinical Medicine.9: 1-7.

Nursiam dan Lastiyono Doso Puteranto, Analisis Efisiensi Pasar Modal Indonesia Periode 1998-2000 (Studi pada PT. Bursa Efek Jakarta), Jurnal Akuntans dan Keuangan, Vol. 3, No. 1, April 2004.

Rusdin. 2008. Pasar Modal: Teori, Masalah Dan Kebijakan Dalam Praktik: Bandung: Alfabeta.

Sambuari, I.B., Saerang, I.S., Maramis, J.B. 2020. Reaksi Pasar Modal Terhadap Peristiwa Virus Corona (COVID-19) Pada Perusahaan Makanan dan Minuman yang Terdaftar di Bursa Efek Indonesia. Jurnal Ilmiah Manajemen Bisnis dan Inovasi Universitas Sam Ratulangi. 7(3): 407-415.

Siswantoro. 2020. Efek diumumkannya Kasus Pertama COVID-19 terhadap Harga Saham dan Total Saham yang diperdagangkan (The Effect of the First COVID-19 Case Announcement on Stock Prices and Stock Trading Totals). Jurnal Akuntansi, Keuangan, dan Manajemen (Jakman). 1(3): $227-$ 238.

Subrata, K., dan Werastuti, D.N.S. 2020. Analisis Reaksi Pasar Pada Penetapan Status Darurat Global Ke Level Tertinggi Terkait Virus Corona Oleh WHO (World Health Organization) Pada Bursa Efek Indonesia. JIMAT (Jurnal Ilmiah Mahasiswa Akuntansi) Universitas Pendidikan Ganesha. 11(2):169177

Sutrisno, Wang. 2010. Manajemen Keuangan, Teori, Konsep dan Aplikasi, Yogyakarta: Ekonisia 
Tandelilin, Eduardus. 2010. Portofolio dan Investasi Teori dan Aplikasi. Edisi pertama. Yogyakarta : Kanisius

Wicaksono, C.A., dan Adyaksan, R.I., 2020. Analisis Reaksi Investor Sebagai Dampak Covid-19 Pada Sektor Perbankan Di Indonesia. JIAFE (Jurnal Ilmiah Akuntansi Fakultas Ekonomi). 6(2):129-138.

World Health Organization (WHO). 2020. WHO COVID-19 Dashboard: Up to date data on pandemic. URL: https://covid19.who.int/?gclid=EAIaIQobChMI9eHJ0vjm7gIVTKaWCh1q g2DEAAYASAAEgKpcfD_BwE. Diakses tanggal 15 Februari 2021. 